\title{
Golgi Vesicles Fused with Invaginated Plasma Membranes in Host Cells Treated with a Host-Specific Toxin from the Japanese Pear Pathotype of Alternaria alternata
}

\author{
Pyoyun Park*, Tohgo OHNo*, Syoyo Nishimura**, \\ Keisuke KoHmoto*** and Hiroshi OTanI***
}

\begin{abstract}
The secretory activity of Golgi bodies in Japanese pear leaves treated with AK-toxin was examined with an electron microscope by staining sections with alkaline bismuth stain as a tracer of Golgi vesicles to discern the viability of the toxin-treated susceptible cells. The toxin caused the invaginations of plasma membranes and the loss of abundant membranous fragments from the invaginated plasma membranes in the susceptible cells. In the susceptible cells treated with the toxin for 1,3 , and $6 \mathrm{hr}$, many Golgi vesicles which were positive to alkaline bismuth stain were present at the peripheral cytoplasm beneath invaginated plasma membranes and some of them fused with the invaginated plasma membranes. The accumulation and fusion of the Golgi vesicles were rarely found in cells of the necrotic susceptible leaves treated with the toxin for $\mathbf{1 0}$ hr. However, the phenomena vere not observed in the toxin-treated resistant cells and the water-treated susceptible ones. The susceptible cells were viable within $6 \mathrm{hr}$ after the toxin treatment because the cells had the high activity of Golgi bodies and the high ability of plasma membranes to fuse with many Golgi vesicles. On the contrary, the susceptible cells appeared not to be viable $10 \mathrm{hr}$ after the treatment because they had both the low activity of Golgi bodies and the poor ability of plasma membranes. The results indicate that the enhanced production of Golgi vesicles may be associated with the viability of cells in the toxin-treated susceptible leaves, and that the produced Golgi vesicles may be supplied for repairing the damaged plasma membranes.
\end{abstract}

(Received April 12, 1988)

Key words: Alternaria alternata, a host-specific toxin, ultrastructural morphometry, Golgi vesicle, plasma membrane modification, membrane-recycling system.

\section{INTRODUCTION}

A host-specific toxin (AK-toxin) from the Japanese pear pathotype of Alternaria alternata that causes black spot disease of Japanese pear is extremely toxic to the susceptible cultivars of Japanese pear, but harmless to the resistant ones. Nishimura and Kohmoto ${ }^{3)}$ state that the host-selectivity may be explained by the presence of the toxin receptor in plasma membranes of susceptible cells, but the absence and lack of the receptor in resistant ones. The binding between the toxin molecules and receptors probably results in rapid change of permeability in susceptible cells. Afterwards, the host cells may pass many metabolic alterations and finally lead to cell

* Electron Microscopic Section, Department of Orthopaedic Surgery, Teikyo University School of Medicine, Tokyo 173, Japan 帝京大学医学部

** Laboratory of Plant Pathology, Faculty of Agriculture, Nagoya University, Nagoya 464, Japan 名古屋大学费学部

*** Laboratory of Plant Pathology, Faculty of Agriculture, Tottori University, Tottori 680, Japan 鳥取大学苌学部 
death. Park et al.$^{4,7,8)}$ reported that the first ultrastructural effect of the toxin appeared on plasma membranes near the plasmodesmata of susceptible cells. The plasma membrane modification is an assemblage of three ultrastructural changes: the invagination, fragmentation and vesiculation of plasma membranes, the deposition of cell wall-like materials and the extension of plasmodesmata. They") also demonstrated in a recent study that cellular sodium ions were leached from the modified sites near plasmodesmata. Until recently, the susceptible cells where the modifications occurred had been interpreted to be killed by the toxin. However, the authors have now suspected the susceptible cells with the modifications of being dead because the toxintreated cells appeared normal even at late period of the toxin treatment. It is unclear whether the appearance of the modifications reveals the sign of indicating the cell death or the process. With these developments, they attempted to examine the activity of plasma membranes and Golgi bodies in host cells by monitoring the number of pinocytotic and free Golgi vesicles to clarify the problem.

\section{MATERIALS AND METHODS}

Cultivars of Japanese pear (Pyrus serotina Rehd.) used were cv. Nijisseiki (sensitive to AKtoxin) and cv. Chojuro (resistant to the toxin). Young leaves of these plants were used in this work. AK-toxin was prepared as described previously7). The upper surfaces of the leaves were injured by using a scalpel. Drops of the toxin solution or distilled water were placed on the wounded portions. These leaves were incubated in a moist chamber for $1,3,6$ and $10 \mathrm{hr}$ at $28 \mathrm{C}$. The treated portions were trimmed with a razor blade. For electron microscopy, the specimens were prepared as described previously"). The ultrathin sections were cut on a Porter Blum MT-1 using a diamond knife. The sections were stained with alkaline bismuth (AB) solution for $40 \mathrm{~min}$ at $40 \mathrm{C}$. $\mathrm{AB}$ stain was used to identify Golgi vesicles in cytoplasm of the leaf cells because it is densely reactive with the vesicles ${ }^{8}$. Some sections were stained with uranyl-acetate and lead-citrate ${ }^{8}$. These sections were examined with a JEOL 100-S electron microscope.

Many electron microscopic negatives were taken at magnification of $\times 3,000$ in the mesophyll cells adjacent to vascular bundle sheath cells of the water- or toxin-treated susceptible and resistant leaves. The negatives were enlarged at a magnification of $\times 25,000$ and printed in printing papers $(8 \times 10$ inches). The cytoplasm was divided into three regions (A, B and C) to examine the distribution of Golgi vesicles (Fig. 1). The cytoplasmic zone that is $0.5 \mu \mathrm{m}$ wide
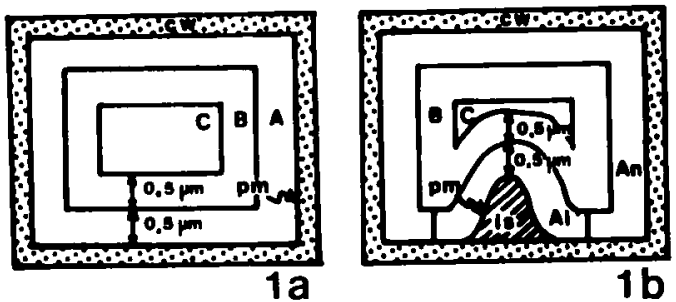

Fig. 1. Partition of cytoplasmic regions of mesophyll cells of Japanese pear leaves treated with AK-toxin and water where distribution of Golgi vesicles was examined. Fig. 1a. Water-treated susceptible leaves and the toxin-treated resistant ones. Fig. 1b. The toxin-treated susceptible leaves. A: $0 \sim 0.5 \mu \mathrm{m}$ innner part of cytoplasm from plasma membrane; B: $0.5 \sim 1 \mu \mathrm{m}$ inner part of cytoplasm from plasma membrane; C: Cytoplasm excepting for $\mathrm{A}$ and $\mathrm{B}$ region; $\mathrm{Ai}: 0 \sim 0.5 \mu \mathrm{m}$ inner part of cytoplasm beneath invaginated plasma membranes; An: $0 \sim 0.5 \mu \mathrm{m}$ part of cytoplasm beneath noninvaginated plasma membrane; CW: Cell wall; pm: Plasma membrane; is: Invaginated space between cell wall and plasma membrane. 
from plasma membranes is A region while the zone $0.5 \mu \mathrm{m}$ wide from the inner border of $\mathrm{A}$ region is $\mathbf{B}$ region. The other cytoplasm is $\mathbf{C}$ region. In the toxin-treated susceptible cells, $\mathbf{A}$ region was further divided into two sub-regions: Ai region beneath invaginated plasma membranes and An region beneath non-invaginated plasma membranes. The distribution of Golgi vesicles and Golgi bodies was examined by monitoring the number of AB-reactive Golgi vesicles and Golgi bodies per $10 \mu \mathrm{m}^{2}$ cytoplasm and the number of pinocytotic Golgi vesicles per $10 \mu \mathrm{m}$ plasma membranes. The cytoplasm and length were measured by using an image analysis computer, MOP videoplan of Kontron. In the measured cytoplasm such as $\mathrm{A}, \mathrm{B}$, and $\mathrm{C}$ region, the areas of chloroplasts, microbodies, mitochondria, nuclei and vacuoles were excluded.

\section{RESULTS}

\section{Alkaline bismuth-stained cells of water-treated host leaves}

AB stain well reacted with cell walls, grana lamellae of chloroplasts, plasma membranes and starch grains in the water-treated leaves as described previously6). Additionally, it was reactive with the carbohydrate-rich substances of Golgi vesicles and electron-opaque fine metal deposits were found in the lunima (Fig. 2). The Golgi vesicles remote from Golgi cisternae had much more reactive metal deposits in the lumina and revealed higher contrast in the vesicular membranes than those adjacent to Golgi cisternae (Fig. 2). The AB-reactive Golgi vesicles were found to fuse with plasma membranes in places. However, Golgi vesicles stained with uranylacetate and lead-citrate contained weakly stained amorphous materials (Fig. 3).

\section{Alkaline bismuth-stained cells of AK-toxin treated host leaves}

AK-toxin used here had caused veinal necrosis in the susceptible leaves $6 \mathrm{hr}$ after the treatment and the necrosis expanded from veins to mesophyll cells in the leaves treated with the toxin for $10 \mathrm{hr}$. However, necrosis never occurred in the resistant leaves treated with the toxin for $10 \mathrm{hr}$.

The toxin-treated susceptible mesophyll cells showed small plasma membrane modifications $1 \mathrm{hr}$ after the treatment. The susceptible plasma membranes first became invaginated at plasmodesmata and then the plasmodesmata were extended. These modifications occurred more frequently in the susceptible cells treated with the toxin for 3 or $6 \mathrm{hr}$ than in the susceptible ones treated with the toxin for $1 \mathrm{hr}$. The spaces between the cell walls and the invaginated plasma membranes usually contained membranous materials, cell wall-like materials, and the tubular structures (Fig. 4). In the susceptible cells treated with the toxin for $6 \mathrm{hr}$, the membranous materials were abundantly detached from the invaginated plasma membranes, and then released into the invaginated spaces. The detached membranes were $10.7 \mathrm{~nm}$ wide while the invaginated or non-invaginated plasma membranes were $7.7 \mathrm{~nm}$ wide (Figs. $4 \mathrm{a}$ and $4 \mathrm{~b}$ ).

A large number of Golgi vesicles were accumulated in the peripheral cytoplasm of the susceptible cells treated with the toxin for $6 \mathrm{hr}$ (Figs. 4 and 5). The Golgi vesicles were distributed alongside the inner side of plasma membranes, especially in the cytoplasm beneath invaginated plasma membranes. Many Golgi vesicles fused with the invaginated parts of plasma membranes (Fig. 5). The fused Golgi vesicles appeared to be an exocytotic type. In some susceptible cells, AB-reactive tubular structures were often observed in the peripheral cytoplasm. The lumina of the peculiar structures contained AB-reactive fine deposits and the membranes of tubular structures had higher contrast as well as Golgi vesicles. It was also found that some of Golgi vesicles fused with the ends of the structures. The structures, therefore, appeared to be formed by the intracellular fusion of many Golgi vesicles. The Golgi bodies of the toxin-treated susceptible cells produced many Golgi vesicles (Fig. 7).

The marked plasma membrane modifications were often found in the necrotic susceptible leaves treated with the toxin for $10 \mathrm{hr}$. The Golgi vesicles fused with the invaginated plasma membranes usually were not seen in the cells (Fig. 8). The cells of the necrotic leaves had electron-dense cytoplasm (Fig. 9). The Golgi bodies of the cytoplasm produced scanty Golgi 
vesicles (Fig. 10). In the toxin-treated resistant leaves, the abnormal accumulation of Golgi vesicles was never observed in the cytoplasm.

Distribution of AB-reactive Golgi vesicles and Golgi bodies in host plants treated with $A K$-toxin and water

The Golgi vesicle per unit cytoplasmic area in the water-treated susceptible cells is almost equal in number to that in the toxin-treated resistant cells (Table 1). On the contrary, the number had increased in the toxin-treated susceptible cells as the time of the toxin treatment was prolonged (Table 1). This tendency was observed within $6 \mathrm{hr}$ after the treatment. In susceptible cells

Table 1. Comparative number of Golgi vesicles and Golgi bodies in mesophyll cells of Japanese pear treated with AK-toxin and water

\begin{tabular}{llccc}
\hline Cultivars & Treatment & $\begin{array}{c}\text { Treatment } \\
\text { time }(\mathrm{hr})\end{array}$ & $\begin{array}{c}\text { No. of Golgi vesicles/unit } \\
\text { cytoplasmic area } \\
\left(10 \mu \mathrm{m}^{2}\right)\end{array}$ & $\begin{array}{c}\text { No. of Golgi bodies/unit } \\
\text { cytoplasmic area } \\
\left.\left(10 \mu \mathrm{m}^{2}\right)^{2}\right)\end{array}$ \\
\hline Susceptible & Water & 1 & 31.7 & 1.46 \\
Susceptible & Toxin & 1 & 36.0 & 1.51 \\
Susceptible & Toxin & 3 & 41.7 & 1.38 \\
Susceptible & Toxin & 6 & 51.5 & 1.03 \\
Susceptible & Toxin & 10 & 1.3 & 0.84 \\
Resistant & Toxin & 6 & 30.4 & 1.27 \\
\hline
\end{tabular}

a) There was no significant difference in the number of Golgi bodies among the toxin-treated and watertreated susceptible cells and among the toxin-treated susceptible and resistant cells although the cells of necrotic leaves treated with the toxin for $10 \mathrm{hr}$ had the less number.

Table 2. Comparative number of Golgi vesicles in cytoplasmic areas (A, B and C area) of mesophyll cells of Japanese pear treated with AK-toxin and water

\begin{tabular}{lcccccc}
\hline \hline & & & \multicolumn{2}{c}{ No. of Golgi vesicles/unit area of cytoplasm $\left(10 \mu \mathrm{m}^{2}\right)$} \\
\cline { 5 - 7 } Cultivars & Treatment & $\begin{array}{c}\text { Treatment } \\
\text { time (hr) }\end{array}$ & $\begin{array}{c}\text { Ai area beneath } \\
\text { invaginated } \\
\text { plasma membrane }\end{array}$ & $\begin{array}{c}\text { An area beneath } \\
\text { non-invaginated } \\
\text { plasma membrane }\end{array}$ & B area & C area \\
\hline Susceptible & Water & 1 & No invagination & 27.2 & 39.4 & 32.6 \\
Susceptible & Toxin & 1 & 48.5 & 26.1 & 47.6 & 47.0 \\
Susceptible & Toxin & 3 & 45.7 & 37.5 & 37.7 & 20.6 \\
Susceptible & Toxin & 6 & 52.9 & 44.0 & 35.6 & 20.0 \\
Susceptible & Toxin & 10 & 1.5 & 1.2 & 0.8 & 0.2 \\
Resistant & Toxin & 6 & No invagination & 26.1 & 37.5 & 28.5 \\
\hline
\end{tabular}

Table 3. Comparative number of Golgi vesicles fused with plasma membranes in mesophyll cells of Japanese pear treated with AK-toxin and water

\begin{tabular}{|c|c|c|c|c|}
\hline \multirow{2}{*}{ Cultivars } & \multirow{2}{*}{ Treatment } & \multirow{2}{*}{$\begin{array}{l}\text { Treatment } \\
\text { time (hr) }\end{array}$} & \multicolumn{2}{|c|}{$\begin{array}{l}\text { No. of Golgi vesicles/ unit length of } \\
\text { plasma membrane }(10 \mu \mathrm{m})\end{array}$} \\
\hline & & & $\begin{array}{l}\text { Invaginated plasma } \\
\text { membrane }\end{array}$ & $\begin{array}{c}\text { Non-invaginated plasma } \\
\text { membrane }\end{array}$ \\
\hline Susceptible & Water & 1 & No invagination & 1.2 \\
\hline Susceptible & Toxin & 1 & 13.6 & 2.6 \\
\hline Susceptible & Toxin & 3 & 25.2 & 3.9 \\
\hline Susceptible & Toxin & 6 & 28.3 & 8.4 \\
\hline Susceptible & Toxin & 10 & 0.7 & 0.1 \\
\hline Resistant & Toxin & 6 & No invagination & 1.5 \\
\hline
\end{tabular}


treated with the toxin for $10 \mathrm{hr}$, Golgi vesicles extremely decreased in number. The abundantly produced Golgi vesicles were localized much more in the peripheral cytoplasm (A region) of the toxin-treated cells, especially in Ai region near the invaginated plasma membranes, than in $\mathrm{B}$ and $\mathrm{C}$ region (Table 2). The Golgi vesicles were found more frequently to fuse with the invaginated plasma membranes rather than with non-invaginated plasma membranes. The number of the Golgi vesicles fused with the invaginated plasma membranes increased from $1 \mathrm{hr}$ to $6 \mathrm{hr}$ after the toxin treatment, and then markedly decreased $10 \mathrm{hr}$ (Table 3). The fused Golgi vesicles usually were a few in the water-treated susceptible cells and the toxin-treated resistant cells. The number of Golgi bodies tended to slightly decrease in the toxin-treated susceptible cells as the time of the treatment elapsed (Table 1).

\section{DISCUSSION}

This study showed that AK-toxin caused the detachment of abundant membranous fragments from invaginated plasma membranes in the susceptible cells of Japanese pear, and induced the high secretory activity of Golgi bodies before the necrosis. The break-down of plasma membranes offered two pathologically significant arguments: the alterations and repair of plasma membranes.

The first argument arose from the difference of membrane-width between the plasma membranes and the detached membranes. The detached membranes were about 1.39 times wider than the intact plasma membranes. This significant difference is noteworthy after considering the function and ultrastrucrture of plasma membranes. A previous study revealed that dilation of the detached membranes was caused by a result of the dilated lipid bilayers ${ }^{5}$. Kanaseki $\left.{ }^{2}\right)$ state that the different width of biological membranes reflects the different functions, and the similar type of the membranes which can fuse each other has naturally the similar width. From his idea, it is presumed that the detached membranes are the denatured parts of plasma membranes and different in function from plasma membranes at ultrastructural level.

The second is an argument for controlling total volume of plasma membranes in the toxintreated susceptible cells. The mechanism that constantly controls the volume has been known as membrane-recycling system in animal cells, especially secretory cells'). In the cells, Golgi bodies get a part of the system supported. When the cells involve the excessive volume of plasma membranes due to active exocytosis, the excessive volume is recovered from plasma membranes into Golgi bodies as endocytotic vesicles to maintain the constant volume. This study revealed the presence of membrane-recycling system in Japanese pear leaf cells. The membranes which were abundantly detached from invaginated plasma membranes probably resulted in decreasing the volume of plasma membranes in the cells. The extreme decrease may cause burst or collapse of the cells. Although the Golgi bodies did not vary in number significantly in the toxin-treated susceptible cells, many Golgi vesicles fused with plasma membranes, especially the invaginated plasma membranes, in the cells where the abundant membranes were lost from the plasma membranes. Quantitative data for distribution of Golgi vesicles showed that they became much more concentrated in the peripheral cytoplasmic region beneath the invaginated plasma membranes than in the other cytoplasmic regions. The results showed that the Golgi bodies produced many Golgi vesicles as complementary membranous supply for lost plasma membranes in the toxintreated susceptible cells. The peculiar complex structures seen in the peripheral cytoplasm of the toxin-treated susceptible cells were formed by fusion of many Golgi vesicles. This also indicated the marked secretory activity of Golgi bodies in the cells. The susceptible cells were still viable within $6 \mathrm{hr}$ of the toxin treatment because the cells had the high activity of Golgi bodies and the high ability of plasma membranes to fuse with many Golgi vesicles. In the cells of the necrotic susceptible leaves treated with the toxin for $10 \mathrm{hr}$, the production of Golgi vesicles and the number of the fused Golgi vesicles decreased extremely, showing that the cells appeared not to be viable. These results suggested that both alteration and repair of plasma membranes 
occurred at the same region where the modifications appeared. The biological significance of cell wall-like materials seen in the invaginated spaces is still speculative.

The authors wish to thank Professor A. Tateishi, Chairman of Department of Orthopaedic Surgery in Teikyo University School of Medicine for his encouragement during this work.

\section{Literature cited}

1. Fujita, H. (1980). Seitainokagaku 31: 2-11.

2. Kanaseki, T. (1975). Kagaku 45: 163-172.

3. Nishimura, S. and Kohmoto, K. (1983). Ann. Rev. Phytopath. 21 : 87-116.

4. Park, P. (1977). Physiol. Plant Pathol. 11: 39-42.

5. Park, P. (1977). Ann. Phytopath. Soc. Japan 43: 475-478.

6. Park, P., Fujiwara, T. and Fukutomi, M. (1977). J. Electron Microsc. 26: 335-337.

7. Park, P., Fukutomi, M., Akai, S. and Nishimura, S. (1976). Physiol. Plant Pathol. 9: 167-174.

8. Park, P., Ohno, T., Kikuchi-Kato, H. and Miki, H. (1987). Stain Technol. 62: 253-256.

9. Park, P., Ohno, T., Nishimura, S., Kohmoto, K. and Otani, H. (1987). Can. J. Bot. 65: 330-339.

\section{和 文 摘 要}

朴 杓允・大野藤吾・西村正暘・甲元啓介・尾谷 浩 : ナシ黒斑病菌毒を処理した宿主細胞における宿 入原形質膜へのゴルジ小胞の骶合

タルジ胞の特異的染色液であるアルカリビスマス液を用いて，AK 毒素を処理した摍主細胞内のタルシ 小胞の数を計測して毒素処理後の宿主稩胞の活性を調べた。本毒素は，宿主細胞の原形質膜を陥入させ陥入 膜から多量の膜片を衰失させる。毒素を 1, 3,6 時間処理した宿主細胞では、フルカリビスマス液に陽性の ヨルジ胞か，樎入原形質膜周辺の細胞質に多数出現し，その多くは陥入膜に融合していた。しかし，毒素 を 10 時間処理した壊死組織の細胞ではゴルジ胞はほとんど琹められなかった。対照区と毒素处理した抵 抗性ナシ葉細胞にはゴルジ胞の異常な集積と融合は観察されていない。毒素処理 6 時間以内では宿主細胞 は，增高したゴルシ活性と多くのゴルシ小胞と融合する能力のある原形質膜を有しているためまだ生きてい るが, 10 時間後ではこれらの活性と能力の著しい低下のため細胞は死んでいると考兄られる。これらの結 果は, ゴルジ分泌活性の增高が細胞の活性と関連をすち, 生産されたヨ゙ルジ小胞は変性原形質膜の攸復を行 っていることを示唆する。

\section{Explanation of plates}

Plate I and II.

Fig. 2. Alkaline hismuth-stained mesophyll cells of water-treated susceptible Japanese pear leaves. Golgi vesicles contained many alkaline bismuth-reactive fine metal deposits. A group of Golgi vesicles remote from Golgi cisternae showed higher contrast of the vesicular membranes and deposition of much more reactive products than those adjacent to Golgi cisternae. $(\times 72,000)$.

Fig. 3. Typical Golgi bodies in mesophyll cells of water-treated susceptible pear leaves. Conventional double staining with uranyl acetate and lead citrate. Slightly electron-dense content was seen inside Golgi vesicles $(\times 64,000)$.

Figs. 4 to 7. Susceptible mesophyll cells of Japanese pear leaves treated with AK-toxin for $6 \mathrm{hr}$. Alkaline bismuth staining.

Fig. 4. A typical plasma membrane modification showing a large invagination of plasma membrane, membranous materials detached from invaginated plasma membranes, tubular structures extended from plasmodesmata and cell wall-like materials. Note that alkaline bismuth-reactive Golgi vesicles (arrowheads) were seen in cytoplasm beneath plasma membranes and to fuse with the plasma membranes. $(\times 72,000)$.

Fig. 4a. Enlargement of a left boxed area in Fig. 4. $(\times 326,000)$.

Fig. 4b. Enlargement of a right boxed area in Fig. 4. The unit membrane of invaginated plasma membranes is $7.7 \mathrm{~nm}$ wide (Fig. 4a) while that of detached membranes is $10.7 \mathrm{~nm}$ wide (Fig. 4b). 
Fig. 5. Accumulation of alkaline bismuth-reactive Golgi vesicles (asterisks) in host cytoplasm beneath invaginated plasma membranes. Note that Golgi vesicles (arrowheads) fused with invaginated plasma membranes. $(\times 60,000)$.

Fig. 6. Tubular structures formed by mutual fusion of alkaline bismuth-reactive Golgi vesicles in host cytoplasm beneath plasma membranes. $(\times 47,000)$.

Fig. 7. Golgi bodies producing many alkaline bismuth-reactive Golgi vesicles. $(\times 41,000)$.

Plate III.

Figs. 8 to 10. Susceptible cells of necrotic Japanese pear leaves treated with AK-toxin for $10 \mathrm{hr}$. Alkaline bismuth staining.

Fig. 8. A large plasma membrane modification showing abundant membranous materials detached from plasma membranes and tubular structures. Note that no accumulation of alkaline bismuth-reactive Golgi vesicles in host cytoplasm beneath invaginated plasma membranes was seen. $(\times 37,000)$.

Fig. 9. Collapsed host cells with plasma membrane modifications. $(\times 13,000)$.

Fig. 10. A Golgi body in necrotic leaves producing scanty Golgi vesicles. $(\times 126,000)$.

Abhreviations used in plates: CW, Cell wall; CWM, Cell wall-like material; GC, Golgi cisterna; GV, Golgi vesicle; M, Membranous material detached from plasma membrane; P, Plasma membrane; PM, Plasma membrane modification; TS, Tubular structure. 


\section{Plate I}

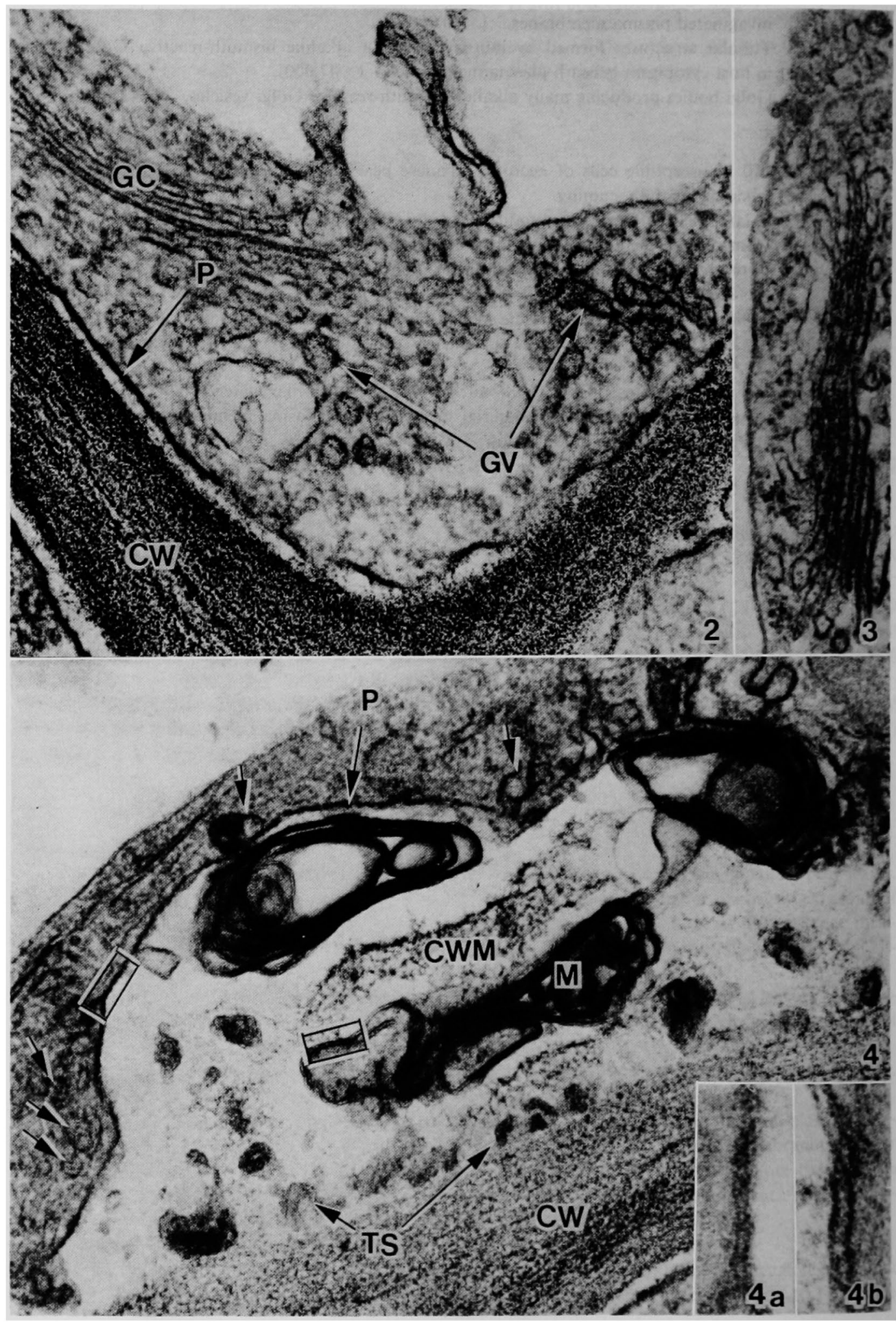




\section{Plate II}

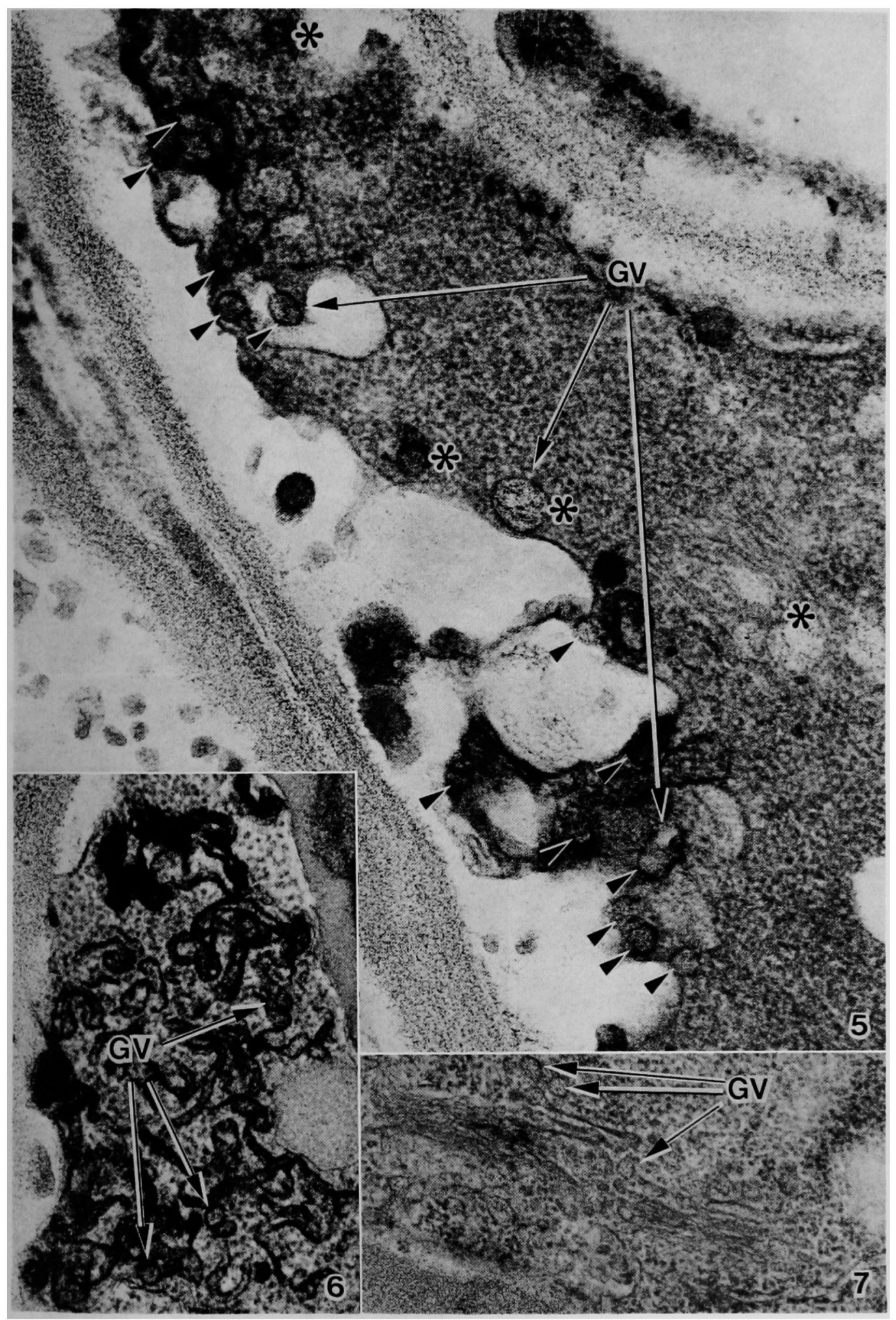




\section{Plate III}

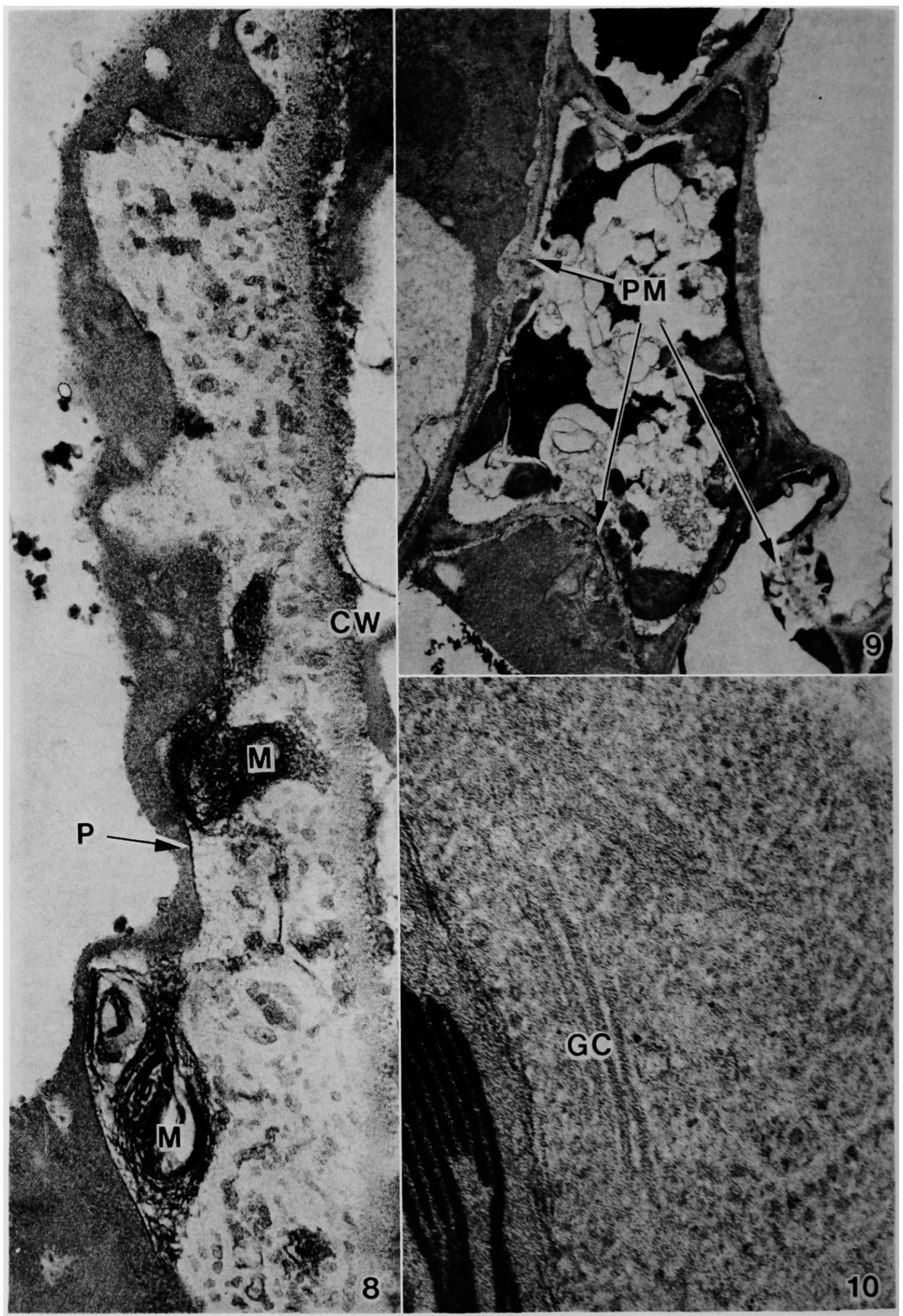

